\title{
1. Higher education, the EU and the cultural political economy of regionalism
}

\author{
Susan L. Robertson, Mário Luiz Neves \\ de Azevedo and Roger Dale
}

\section{INTRODUCTION}

This chapter aims to make a substantive and theoretical contribution to the understanding of the role of higher education in regional governance projects. Substantively, through an exploration of two interlinked, ongoing regional governance projects - the creation of a European Higher Education Area (EHEA) by 2010, and a European Research Area (ERA) by 2014 - we will examine the ways in which higher education is mobilized in the constructing of Europe as a globally competitive region.

'What is new?', one might ask, and at one level we agree. Researchers examining the ongoing Europeanization of once determinedly national higher education institutions and sectors have described in detail the launch of the Bologna Process in 1999 aimed at reforming degree architectures and systems of credit transfer amongst European universities, and its rolling out across the European Union (EU) and beyond (cf. Huisman and van der Wende, 2004; Keeling, 2006; Ravinet, 2008). They have also shown the ways in which the 2000 Lisbon Agenda, to make Europe a competitive region and society buoyed by good jobs and social cohesion, has been advanced by the European Commission, and have reflected on the central role that universities are expected to play in this (cf. Gornitzka, 2005). Yet at another level, what is missing in these accounts is a critical account of the way in which these higher education regional projects are tied to ongoing challenges facing national states as they manage crisis tendencies in their domestic economies, Europe's own claim to statehood, and the role that higher education regionalizing processes might play in this.

In this chapter we aim to offer a more complex reading of these regional higher education projects that we show have cultural, political and economic (Robertson and Dale, 2015) dynamics at play tied to the 
ongoing transformations of the state. In tracing out these projects over the period 2000 to 2015 , we show the ways in which higher education is being drawn into the logic of capitalist expansion and world market-making. The 'region' - in this case two overlapping but distinct higher education regional projects - is not only dependent on, but has ongoing effects upon, the socio-political and spatial relations between domestic economies, the (supra-national) region, and the 'extra-regional', or global. In sum, these are novel, spatial strategies deployed by the state and allied social forces which in turn transform the state, the region, and overlapping higher education sectoral projects.

This leads to our second aim: to draw on our critical reading of these developments in order to contribute to current theorizing on regions. We are not alone in noting that conceptual work on regions is a minefield; this is in part because, as Hettne (2005: 543) observes, the approach to regionalisms varies as a result of different academic specialisms which means that 'regionalism means different things to different people'. Furthermore, as Cammack (2015: 3) points out: 'the diversity of regional projects and impulses towards them rules out a substantive theory of regionalism, as such, and makes it unlikely a single trend informs all contemporary manifestations of regionalism'.

But we also detect a further issue: in many cases work on regions tends to be driven by what Cammack (2015) calls 'regionalist ideology', fitting the case to the theory, rather than putting theories into a dialogue with facts and events. In the latter case we would expect to see variegation in regional projects and processes arising from the ways in which logics and mechanisms encounter the specificities of time, space and social arrangements (Robertson, 2014). Furthermore, it matters in important ways if regional projects are advanced by actors such as states (national, subnational), particularly in economic restructuring, as the state is a very particular kind of institution in capitalist societies and plays an important role in managing the challenges of ongoing economic development. By way of contrast, some regional projects, such as the one advanced by the Council of Europe in the fading shadow of the Second World War, might be viewed as a political and cultural project aimed at building regional cooperation within Europe and with its close neighbours.

At its most basic, and to avoid regionalist ideology, we take Ercan and Oguz's (2006), Hameiri's (2013) and Cammack's (2015) point, and suggest that one way we might approach regional projects and region-building is to pose a set of questions that in turn might reveal the logics and processes at work in producing regional space and its social relations: What underlying logics are at work? What is the ideational basis of these (political, cultural, economic) projects? How are meanings brokered, and by whom? 
What processes, mechanisms and contradictions are at play? With what outcomes? For whom? How are multiple overlapping spatial projects managed? And so on. In our own response to these questions, we will argue for a way of researching regions conceptually and methodologically that focuses on a cultural political economy (Robertson and Dale, 2015) of regionalism; and in our case, higher education sectoral regionalism.

Our chapter is developed in the following way. We begin with some remarks on a cultural political economy of region-making. The six sections which follow trace out the development and ongoing recalibration of the EHEA and ERA as responses to political and economic crises, including the current challenges posed by the 2008 financial crisis. We conclude with a section on conceptualizing and theorizing regional projects as the ongoing manifestation of state-regions-frontier relations.

\section{A CULTURAL POLITICAL ECONOMY OF REGION-MAKING}

Why a cultural political economy of regionalism? A key argument we will be advancing here is that over time, and as a response to changing conditions (in this case, pressure to develop competitive services and knowledgebased economies), sectoral regions like the EHEA and the ERA, are the outcomes of territorially-based formal and/or informal arrangements arising from strategically selective socio-spatial projects and processes advanced by: (1) nationally-located states who strategize blockages to, and crises within, capitalist development trajectories by managing the governance of the territorial boundaries of the state - in this case, their regional mode - in turn transforming the nature of state space as simultaneously composed of regional and national frontiers (Jayasuriya, 2003; Hameiri and Jayasuriya, 2011); (2) regional state actors who mobilize power, resources, and the right to legitimate rule, enabling them to advance the region 'in and for itself' within and beyond the region (Cammack, 2015); and (3) 'extra-regional' or global actors and their institutions (neighbourhood economies; distant strategic domestic economies; old colonial relations and networks; emerging regions such as the Association of Southeast Asian Nations - ASEAN, the Southern Common Market -MERCOSUR and the Bolivarian Alliance for the Peoples of Our America - ALBA; new inter-regional formations) which are enrolled in, and transformed by, these regional state governance projects (Robertson, 2010; Azevedo, 2014). These dynamics are simultaneously cultural (meaning-making, subjectivities), political (power relations, state) and economic (logic of world market-making, capitalism). 
It is worth reiterating here that just as the national scale and the state are not reducible to each other, so also 'states and regions are not identical phenomena; both are manifestations of struggles over the territorial, institutional, and functional scope of political rule' (Hameiri, 2013: 314). That is to say, a region (as in this case, at the supra-regional scale) is a socio-spatial manifestation of a particular organization of state rule, just as the national scale is. These state strategies and their spatial form also build upon, are challenged by, or replace, existing formal and informal state and other institutional, arrangements in a dynamic and changing way. However, what Hameiri (ibid.) underplays, and thus underestimates, is the underlying logic and role of the state in creating the conditions for the expansion of an evolving world market (now including higher education even more directly) (political economy) and the ideational (cultural) content of the state's political projects and their rule, including the ongoing work of the state in securing commitment and consensus through control over meaning-making and processes of socialization (cultural, political). And as we will see in this chapter, the spatial organization of state power, in particular its national, regional and global frontiers, and the ideational content of the state's project, are dynamic, shifting and contested.

The higher education regionalizing projects that we examine in this chapter are an outcome of political projects aimed at constituting and making governable a (competitive) European higher education space and knowledge-based economy. However, it is also clear there are distinctive phases in this project; the outcome of shifts in the balance of social forces and the subsequent recalibration and rearticulation of the socio-economic content of the political project as a result of the ongoing crisis tendencies within capitalism, issues of legitimation, and concerns over social cohesion. Focusing on the current moment of this project, we argue that 'regulatory regionalism' is only one form of territorial frontier, and that a global frontier is also evident, arising from Europe's claim to contingent territorial sovereignty (Elden, 2006) and statehood as a region 'in and for itself'; Europe's extension of its political project in relation to other geostrategic claims; the attractiveness to domestic actors in neighbouring and more distant economies and the usefulness of Europe's higher education tools for brokering the internal transformations; the desire of globally oriented export and import higher education institutions and domestic economies beyond the borders of Europe to align their architectures and regulatory frameworks to maximize market position; and the emergence of Europe's normative power on the global stage. 


\section{REGIONAL FRONTIERS AND THE MAKING OF POST-WAR EUROPE}

The creation of a coherent and competitive Europe has its antecedents in the 1950s where higher education initiatives began to play a role (Corbett, 2005; Hingel, 2001). However, between the 1950s and early 1990s, the EU's higher education project was almost entirely intra-regional in its ontology and outcomes. With the notable exception of the United Kingdom (and to a lesser extent France and Germany), the internationalization of study programmes, curricula, student mobility and research career paths was primarily oriented towards European partners and Europeanizing processes. Key markers were the institutionalizing of regular meetings between the European education ministers, the eventual creation of the European University Institute in Florence in 1971, and the establishment of the EU's Erasmus mobility programme in 1987 to facilitate the movement of students and staff between universities of the member states.

The main policy aims embedded in these European-level initiatives were to produce European-minded citizens engaged with the expanding Community (and European Commission) and committed to the concept of European culture and values. EU President Jacques Delors 'had a highly developed idea of education and the part it could play in his strategy for advancing European integration via the single market' (Corbett, 2005: 121). Two concerns came together which it seemed higher education programmes could mediate: how to create a European single market, on the one hand, and a European citizen, on the other. Harnessing commitment to the European project was viewed as essential in order to combat narrow nationalism as an impediment to the advance of Europe as a political and cultural project.

In 1992, a single market and European Union were announced by the Treaty of European Union and signed at Maastricht by the heads of the European Community's member states. The Maastricht Treaty acknowledged the European Union's direct role in education whilst attempting to limit the European Commission's room for manoeuvre by restricting European-level action to 'supplementary' activities. Whilst the Maastricht Treaty appeared to suggest that the EU's role would be modest, under Delors the European Commission (EC) had ambitions to develop a more comprehensive policy for higher education at the European level.

The 1991 Memorandum on Higher Education shows that higher education 'had already become part of the Community's broader agenda of economic and social coherence' (Huisman and van der Wende, 2004: 350). The Commission quickly made an internal assessment of the EU's 
programmes and developed a new strategy to exploit the opportunities opened up by the Maastricht Treaty's acknowledgement of the 'European dimension' in education. The Commission also began to look outward, beyond the region. It established higher education collaborative programmes with non-EU countries through initiatives such as the América Latina - Formación Académica (ALFA) programme in Latin America; the development of the Tempus cooperation programme with the Western Balkans, Eastern Europe, Central Asia and neighbouring Mediterranean countries; and Asia-Europe relations through Asia-Europe inter-regional structures such as Asia-Link (Robertson, 2008b). However at this point these programmes tended to be based on cultural cooperation and exchange objectives, and were not well coordinated with the emerging policy programme for education within Europe.

To make sense of the politics behind the Memorandum and the events that followed, it is crucial to consider the changing nature of the wider economic and geopolitical context that Europe's member states found themselves in. In 1991-1992 the biggest economies (including Germany) experienced a recession which increased the number of unemployed graduates in Europe (Teichler and Kehm, 1995). This provided some legitimacy for the EC's higher education project. However, of greater significance were the wider changes taking place in the global economy as a result of economic globalization, the transnationalization of production and finance, and the ideological shift from Keynesianism toward neoliberalism (Cox, 1996: 259-260). These structural changes in the global economy had implications for the European project as they directly affected the restructuring of the EU. To be competitive in the global economy, Europe had to transform itself along free trade and free market lines. As Bieler and Morton (2001: 5) argue:

the deregulation of the national financial markets was institutionalized in the Internal Market Programme ... while the shift toward neo-liberalism was expressed by the very nature of the Internal Market Programme and its drive for liberalization and the neo-liberal convergence criteria of EMU [European Monetary Union] focusing on low inflation and price stability.

\section{EUROPE, GLOBAL COMPETITIVENESS AND THE CREATION OF KNOWLEDGE-BASED ECONOMIES}

The imperative to advance Europe as a political and economic project more generally, and a knowledge-based economy most specifically, is linked to the United States of America (USA) and Europe's declining share of goods production globally. For this reason, both the USA and the EU 
have shared a common interest in expanding the global services economy including the restructuring of higher education as a market, as an engine for innovation, and as a key sector in developing new forms of intellectual property. And as Hartmann (2008: 210-211) notes, whilst the USA dominates world trade in commercial services, with 14.3 per cent of the world's share (WTO, 2007: 12), the combined share of European member states (now 27) generates around 46 per cent. This share has increased the aspiration and capability of the EU to also set standards in the emerging global service economy, giving further impetus to the struggle between Europe and the US in providing normative leadership over the development of a globally competitive, services-based economy.

In 2000, the European Union's educational activities were given a significant boost by the 'Lisbon Strategy' which famously declared: 'the European Union must become the most competitive and dynamic knowledge-based economy in the world capable of sustainable economic growth with more and better jobs and greater social cohesion' (European Council, 2000). The Lisbon Strategy provided a mandate and an agenda for extending the reach of Europe's policy responsibility deeper into national territory - education - and ultimately outwards to the rest of the world. The Strategy also confirmed a neoliberal understanding of higher education's contribution to the socio-economic well-being of the region; building and securing human capital for a knowledge-based economy.

In January 2000, upon the proposal of the European Commission, a decision was also taken to establish a European Research Area (ERA), with the principal explicit objective of supporting a knowledge-based economy on a European scale under the framing of a 'Europe of Knowledge'. The European Commission insisted on the urgency of the task, arguing:

without a co-ordinated impulse and a determined effort to increase and better organise the European research effort, Europe might compromise its chances of taking full advantage of the potential offered by the transition to a knowledgebased economy and society. This will not be without its negative impact on growth and employment. (European Council, 2000)

The invoking of the idea of a European research effort here is important, as this also demands new forms of cultural identification for researchers and their research efforts.

Similarly, the Lisbon Summit in 2000, and the strategy that was articulated there, was intended to 'find a European way to evolve to the new innovation-and knowledge-based economy using distinctive attributes ranging from the preservation of social cohesion and cultural diversity to the very technological options' (Rodrigues, 2002: 14). Rodrigues's account of the Lisbon process is particularly important for she was not only a 
professor at the University Institute, Lisbon and president of the Social Sciences Advisory group to the European Commission, but also special adviser to the Portuguese Prime Minister, Antonio Guterres, in charge of preparing the Lisbon Summit.

The strategies that informed Lisbon drew self-consciously upon the expertise of European researchers, including evolutionary economist Bengte-Ake Lundvall, French regulation theorists Aglietta and Boyer, Gosta Esping Anderson's work on comparative systems of welfare, and Manuel Castells' concern with informationalism and emerging network societies. Taken together, their work was seen by the Lisbon architects to 'provide interesting tools with which to think about the role of structural policies and of institutional reforms in fostering growth and employment' (Rodrigues, 2002: 13).

Rodrigues's (2002: 10-13) account of the theoretical paradigm used to shape the Lisbon agenda is particularly interesting. She argues that there was a rejection of simple economic modelling and methodological individualism in favour of a more complex conceptual framework. This ideational moment represents an explicit rejection of a model of economic development based on Homo economicus. It also drew heavily on cultural ideas of learning and the importance of the socially embedded nature of economies. In wider political terms, this ideational agenda reflected the dominance, still, of centre-left governments in Europe and their respective politics (Collignon, 2006: 5), although this hold was increasingly tenuous and under pressure from social and political forces committed to neoliberalism and neomercantilism (Apeldoorn, 2001: 78).

The main strategic orientations of Lisbon 2000 thus combined supply-side economics with macroeconomic and social concerns: to develop information technologies, research and development (R\&D) policy for institutions, enterprise policy, economic reforms that targeted job creation, macroeconomic policies that focused on employment and structural change along with education and training, a renewed social model, new priorities for schoolbased education, active employment policies focused on lifelong learning, new social protection politics, national plans to reduce social exclusion, and improved social dialogue between European civil society, the economy and structures of government (European Council, 2000). The European Council, however, faced a major challenge: of how to get the support of national governments. This is because member states want to keep control over their own agendas, and because national policy preferences, when taken together from across Europe, are much more heterogeneous. Yet delegating more power to the EU in order to undertake the tasks outlined above-particularly in those areas, like education, where the principle of subsidiarity invokes sensitivities around boundaries - is a highly political issue. 
The Open Method of Coordination (OMC) was invented to overcome this problem. The OMC is an open intergovernmental process of policy coordination to enhance integration, where 'open' means soft governance (Zeitlen et al., 2005). Governments are urged to commit themselves to common policy objectives, while implementation is left to them. To ensure the direction of implementation, a series of structural indicators or benchmarks were developed which enabled member states to see their progress in relation to each other (benchmarking), backed up by peer learning, peer review and the exchange of good practice. Walters and Haahr (2005: 116, 120) argue that not only did benchmarking open new ways of historicizing and particularizing European integration, but also the OMC deployed a range of technologies to foster agency within and across the governmental apparatus of local, national and European institutions.

\section{'NEW LISBON': RECALIBRATING REGIONAL PROJECTS AND SPATIAL FORM}

However, by 2005, the 2000 Lisbon strategy was already in crisis. The Mid-Term Review (European Commission, 2005b), informed by the work of the High Level Group chaired by Wim Kok (2004), concluded that the Lisbon Strategy had failed to deliver satisfactory economic growth, and that Europe was falling far behind both the USA and Asia.

The spectre of China and India, as threat and opportunity (Kok, 2004: 12), now added a new level of threat from external challenges. For Europe to compete it needed to:

develop its own area of specialisms, excellence and comparative advantage which inevitably must lie in a commitment to the knowledge economy in its widest sense ... Europe has no option but to radically improve its knowledge economy and underlying economic performance if it is to respond to the challenges of Asia and the US. (Kok, 2004: 12)

Europe was represented as a long way from achieving the potential for change that the Lisbon 2000 strategy had promised to deliver. The problems were seen to lie not only in difficult economic conditions which had faced the US and Europe with the dot.com collapse, but in 'a policy agenda which had become overloaded, and in failing coordination and sometimes conflicting priorities' within member states and across the region (European Commission, 2005a: 4).

The EC's 'new Lisbon' Communication argued that a new start was required, with investment, innovation and jobs at the centre (EC, 2005a: 4), whilst macroeconomic management and social cohesion - reflections of 
the dominance of centre-left governments in Europe at the time when the Lisbon agenda was negotiated (Collignon, 2006: 5) - were now represented in entirely economic, rather than in social terms (as a socially inclusive economy; see European Commission, 2005a: 26). This new ideational moment combined a Schumpeterian paradigm focused on innovation and entrepreneurship, human capital theory, supply-side economics, and freer conditions of trade; all considered important for world market-making advanced through regional frontiers. The Presidency Conclusions of the European Council acknowledged the mixed results of Lisbon, and called for urgent action in the relaunch of the Commission's proposed 'new' Lisbon Strategy (European Council, 2005: 3).

The 'new' Lisbon Strategy reflected an important shift in the nature of the political project driving higher education regionalism. This project now embraced a new imaginary as to how a European knowledge economy could be secured. While continuing many of the themes in the first Lisbon agenda, in a final Communication by the EC tabled in 2003, The Role of the Universities in the Europe of Knowledge (TRUEK) (European Commission, 2003), ideas such as innovation, knowledge and education, whilst present in the Lisbon 2000 and the TRUEK discourses, were now moved to centre stage, and given new meaning. For instance, with innovation, particular areas - digital technologies, biotechnology and the environment - were now regarded as key to 'making a reality of our vision of a knowledge society' (EC, 2005a: 8). In 2012 the ERA was again tasked with developing, by 2014, a:

unified research area open to the world, based on the Internal Market, in which researchers, scientific knowledge and technology circulate freely and through which the Union and its Member States strengthen their scientific and technological bases, their competitiveness and their capacity to collectively address grand challenges. (EC, 2012)

\section{BOLOGNA: REGIONAL GOVERNING OF NATIONAL HIGHER EDUCATION SPACES AND THEIR RELATIONS}

The Lisbon 2000 agenda for higher education was paralleled by the Bologna Process, a distinctive and ambitious project driven by national governments and other key stakeholders to create a common degree architecture and a European area for higher education. The Bologna Process had its roots in a strategic articulation between domestic and regional agendas. Following a meeting in 1998 in Paris to celebrate the 800th anniversary of the Sorbonne, French Minister for Education Claude Allègre 
secured the agreement of the German, Italian and United Kingdom education ministers: to commit their countries to a new architecture for higher education (Ravinet, 2008). This architecture would build upon the Convention for the Recognition of Higher Education Qualifications in the European region (Lisbon Convention) which had been signed in 1997. Allègre argued that in order to develop a knowledge-based economy, Europe needed to both emulate the US system, and to stem the flow of European graduates to the US.

The following year the Bologna Declaration (1999) committed 29 signatory countries to six 'action lines' directed towards establishing a European Higher Education Area (EHEA) to be realized by 2010. Within this 'Area', staff and student mobility was to be enhanced by the alignment of national quality assurance mechanisms, compatible degree structures, the adoption of a credit transfer system, and a common way of describing qualifications to be outlined in a personal 'diploma supplement'. Taken together, these regulatory mechanisms were viewed as enabling Bologna to act as a vehicle for raising the attractiveness of Europe as a destination for study, and thus an education market worldwide (Zgaga, 2006: 10).

The Bologna Process is a voluntary international agreement, situated outside the European Union's formal governance framework, although it is driven by EU, and increasingly European Commission, interests and promotes many initiatives (such as the European Credit Transfer System, ECTS credit system) originally piloted by the European Commission (Keeling, 2006). 'Convinced that the establishment of the European area of higher education required constant support, supervision and adaptation to the continuously evolving needs' (Bologna Declaration, 1999), the European education ministers decided to meet regularly to assess progress, transforming the Bologna commitment into an ongoing policy process (via a Bologna Process Ministerial Conference held every two years).

Membership of the Bologna Process and the associated European Higher Education Area (officially launched in 2010) has since increased to include, by late 2015,47 countries containing around 5600 public and private institutions with more than 16 million students. The European Higher Education Area includes Russia and Southeast Europe; it thus extends far beyond the European Union as a constitutional entity. New countries continue to be negotiated in as part of an ongoing process of expansion and integration of broadly European and neighbouring countries into the European Higher Education Area. In these cases, a broadly agreed roadmap is put into place, overseen by the Bologna Follow-Up Group, which in turn reports to the European Council of Ministers. In 2016, the latest country negotiating entry to the EHEA was Belarus. 
Determining the ongoing basis of membership of Bologna has been an important geostrategic project. Initially, as Hartmann (2008) points out, membership of Bologna was based broadly on signatories to the Lisbon Convention (1997). For historical reasons this included the United States, Canada and Australia, via the United Nations Educational, Scientific and Cultural Organization's (UNESCO) definition of Europe (the US and Canada signed in 1975, Australia in 1986) (Hartmann, 2008: 213). This meant that these countries, most importantly the US, had a say in the drafting of the initial Bologna Process. Mindful that membership had to be more than Europe and the accession countries (in that it needed to include Russia but not its competitor, the US), some skilful political manoeuvring was required. The Lisbon Convention, as the basis for formal membership of the Bologna Process, was jettisoned in 2003 in favour of the Council of Europe's European Cultural Convention, thereby excluding the US, Canada and Australia. Hartmann (2008: 214) argues that this was one of a series of moves by Europe to challenge the imperial role of the US in standard-setting, turning it simultaneously into both a rival as well as a model. This dual-track membership of the EU, on the one hand, and the EHEA, on the other, also has a third track that includes countries with observer status, for instance China.

In 2009, at the Bologna Ministerial Meeting held in Leuven/Lourvainla-Neuve, it was decided to establish the Bologna Policy Forum in recognition of its diverse, beyond-EHEA membership, with representatives from Australia, Brazil, Canada, China, Egypt, Ethiopia, Israel, Japan, Kazakhstan, Kyrgyzstan, Mexico, Morocco, New Zealand, Tunisia and the USA, along with the International Association of Universities. The Bologna Policy Forum, a wider group than the EHEA, committed itself to developing cooperation on a range of policy issues.

The Bologna Follow-Up Group (BFUG) has the main responsibility for advancing the ongoing policy agenda for the European Higher Education Area and its consolidation. It is composed of a BFUG Board, a Secretariat, working groups and activity groups (Figure 1.1). With Eurostat, Eurostudent and Eurydice, the BFUG collaborates on the Bologna Process Implementation Report, the first report released in 2012; the second in 2015. This report is currently published by the European Commission.

The BFUG has responsibility for organizing the activities of the Bologna Policy Forum, the ongoing Bologna Ministerial Meeting held every two to three years, along with ensuring the working and advisory groups continue to operate effectively. BFUG has a full-time permanent Secretariat (currently a head and four members who have been seconded from EHEA member countries) whose main tasks are to provide administrative and operational support to the BFUG and its Board, to support 


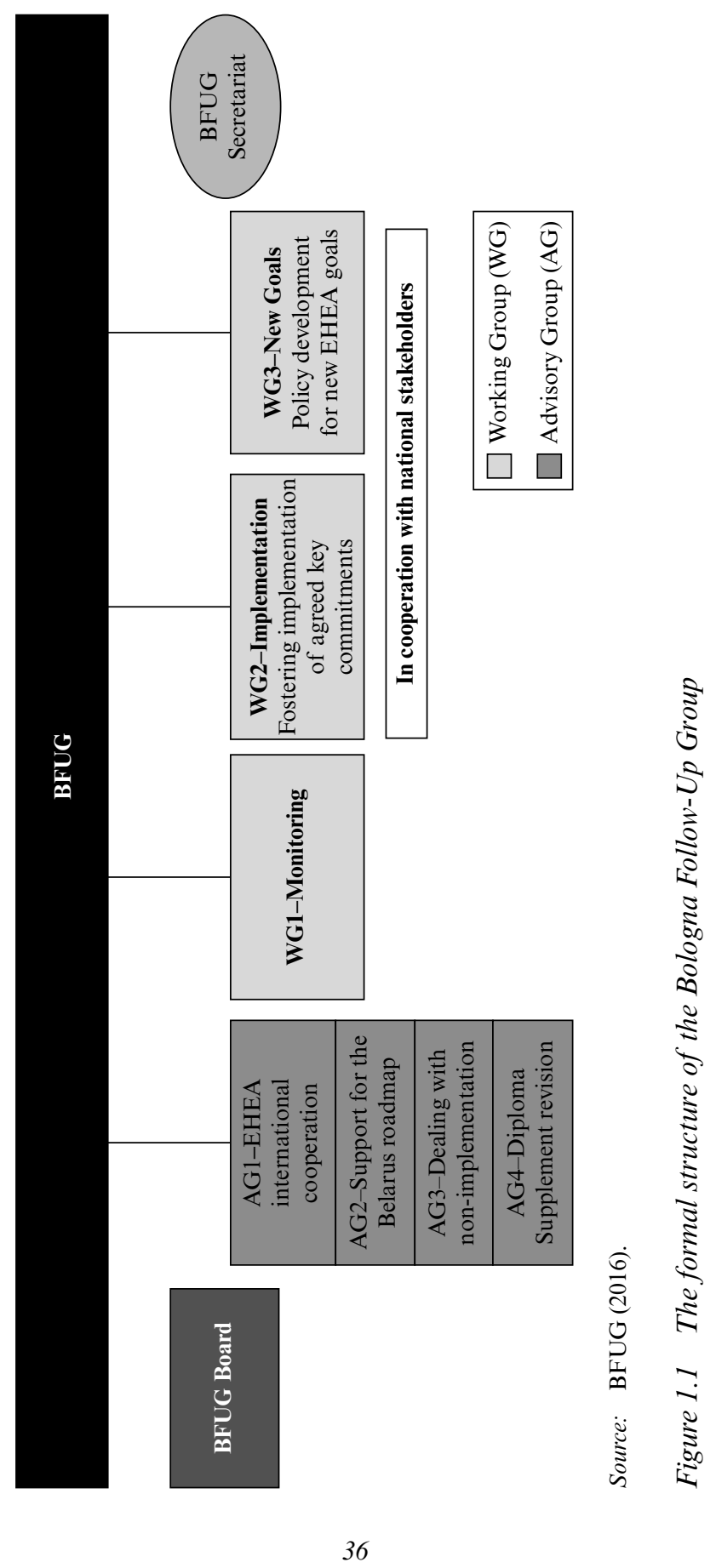


all working and advisory groups, to act as an internal and external contact for the EHEA, prepare both the Ministerial Conference as well as the Bologna Policy Forum, and maintain the EHEA website. Despite this thickening institutional structure at the level of the executive (if we can call the BFUG that), material support from the European Commission, the Council of Europe (see Melo, Chapter 2 in this volume), and national governments, there is increasing disquiet about levels of commitment and progress regarding the Bologna instruments; a question that we address below in the section on crisis and austerity and its impact on progress since 2010.

The EHEA has continued to expand, with multiple-track membership from the EHEA and beyond. This multiple-track membership is reflected in the ongoing structure of the BFUG; in the Leuven/Lourvain-la-Neuve Communiqué, it was decided to signal the equal footing of EU versus non-EU members of the EHEA. The Bologna Process is now co-chaired by the country holding the EU Presidency and a non-EU country, with the division of labour negotiated between the two co-chairs. This multiplicity of memberships and its evident spatial sprawl raises important questions about the overall coherence of the Bologna Process, and the ambiguous role it might play in a region 'for itself', as well as in creating further efficiencies for global competitiveness. However, as Harmsen (2013: 11) observes, this 'pick and choose' 'looseness' has its costs in that there are quite different levels of participation amongst member states. This is an issue for representatives in the Process. But perhaps what we also see here are the residues of other cultural and political projects: a post-war Council of Europe spatial form aimed at advancing European civility via academic cooperation and still visible in the Bologna Process, versus a marketoriented project tasked with making higher education institutions visible destinations for fee-paying students, as well as an attractive destination for researchers to remain in Europe.

The BFUG's Activity Group on International Cooperation continues to build upon an earlier mandate (from the London Ministerial Meeting held in 2007); to elaborate and agree upon a strategy for the external dimension in order to strengthen the attractiveness of the EHEA (Zgaga, 2006). But what is also interesting here are the ways in which these strategies work to advance the region not only in but also for itself on a global stage. This strategy, to be with other regions rather than with countries (BFUG, 2005), thus means developing regions of priority interest for Europe. The EC in particular has managed to advance this objective, often through financing meetings, providing expertise, and having ready-made governance mechanisms available for borrowing and use. We turn to these dynamics in the following section. 


\section{GLOBAL FRONTIERS AND EXTRA-REGIONAL DYNAMICS}

If higher education had been oriented toward managing the territorial project and its politics within the expanding region as a result of different stages of accession, from around 2003 onwards the various political institutions of Europe, in particular the EC, began to pursue a more explicit extra-regional globalizing strategy. This has had direct and indirect effects on higher education as a sector. The direct effects are the outcomes, both within and outside of Europe, of explicit strategies to realize a competitive European higher education area and market following the launch of projects such as the Erasmus Mundus programme, the Neighbourhood Policy, and the mobilization of old colonial links to align with Europe's market interests. The indirect effects are the consequences of the reactions to this strategy in key domestic economies in the global political economy, where the Bologna architecture had become increasingly viewed as variously a threat (USA, Australia), as a model for domestic restructuring (USA, Brazil, China), and as the basis for new regional projects and higher education architectures around the globe (Africa, Latin America, ASEAN).

We discussed earlier one of the triggers for this change in strategy: the view of the Mid-Term Review that Europe was falling rapidly behind both the USA and Asia. This was added to by the spectre of the rise of China and India, as both threat and opportunity (Kok, 2004: 12). The EU Commission President Jose Manuel Barroso delivered a stirring speech at the European University Association convention in Glasgow entitled 'Strong Universities for Europe', complaining that the state of education in Europe compared to other world regions was nothing short of 'miserable' (Barroso, 2005: 25).

In a new departure, the Commission gave direct recommendations as to how universities' structures of governance, financing and research management (including performance measurements and incentives) should be 'modernized' to enable Europe to compete in the global competition for minds and markets (European Commission, 2005b, 2006). This included bringing 'third countries' into cooperation agreements to stem their flow to the US. Education also became an important area of sectoral dialogue with a number of Asian countries, including China. The EU's global talent strategy also sought to attract leading European researchers back to Europe by refining the Marie Curie policy and programme instruments.

Higher education thus became deeply incorporated into the European Union's drive to improve its economic position and influence around the globe. Crucial to this process was the remarkable unfolding, though uneven embedding, of the Bologna Process and its various 
instruments including the Tuning Programme (2003-) to translate existing disciplines of study into competencies, and the establishment of a European Qualifications Register (2008-) to ensure the quality assurance of higher education providers. These are simultaneously cultural, political and economic dynamics in the making of the HE region where new meanings and identities are being brokered, and new social relations pursued in efforts to bring higher education more directly into the making of world market-making.

In sum, the techniques of regional governance have their potency, not only in terms of internal regulation, but also as having the potential to challenge the basis of normative leadership in the education services sector. This has been given considerable impetus by the direct and indirect effects of Europe's higher education project on other domestic economies and nascent regional ambitions within the near region, and beyond.

In the United States, there has been growing interest in the European regional project. Admiration had been expressed for the rapidity of the European changes and the strength of the political will backgrounding them (Jaschik, 2006; Adelman, 2008). By implication, this would mean the loss of a competitive advantage for the US if it did not offer an internationally attractive model of higher education to power the US shift to a services-based economy. As Adelman noted: 'The core features of the Bologna Process have sufficient momentum to become the dominant global higher education model within the next two decades. We had better listen up' (Adelman, 2008: v). One effect was to fuel debate around a 'crisis' in US higher education, and specifically the need to review marketing, visa and admissions processes to stem the decline in share of international students that had followed in the wake of September 11 (Robertson and Keeling, 2008; Adelman, 2008). By 2009 more radical experiments were also under way in three US states (Utah, Indiana and Minnesota), drawing upon one of the Bologna Process's key instruments: 'Tuning Educational Structures in Europe'. Tuning is a project aimed at converting curricular into learning outcomes, enabling the translation of programmes offered in different institutions into a common learning metric.

The USA's response to Europe can be contrasted with the Australian response, which views winning market dominance more clearly as a numbers game. In April 2006, Julie Bishop, the then Australian Minister for Education, Science and Training, tabled a paper entitled 'The Bologna Process and Australia: Next Steps'. This official response to the Bologna Process claimed that Australia must ensure compatibility to Bologna or face the risks associated with being 'a Bologna outsider' (Bishop, 2006). Viewed in this way, the European higher education developments represent a major threat for a number of reasons. First, there is a steady flow of students from Europe; being Bologna-compatible enables and enhances these movements, 
as students would exit an Australian university with a qualification that is also acceptable in the European labour market. Second, the Australian government is well aware that the European Commission has used a number of instruments to create linkages and partnerships in the Asian and Latin American regions (Robertson, 2008a) in order to advance EU economic interests. If Europe were to become a desirable destination for Asian students because of its competitive fee structure, status of universities and the increasing tendency to teach in English at graduate level, then Europe might also threaten Australia's dominance in the market. By April 2007, Australia had signed a joint declaration with the EU to become Bologna-compatible and strengthen cooperation to cover issues of quality assurance, benchmarking and indicators, and qualifications frameworks (Figel and Bishop, 2007). These programmes are seen by the Australian federal government as being critical to developing the new 'globally aware' Australian worker and citizen.

The Bologna Process and its role in the creation of a European Higher Education Area has clearly inspired more strategic ways of thinking about regions and the value of creating and institutionalizing the role of education in regional relationships. Whilst education has been on the agenda in early regional forums such as the Asia-Pacific Economic Cooperation (APEC) (Dale and Robertson, 2002), Bologna offers a different kind of imaginary, creating a regional higher education architecture which offers the possibility for a single market for higher education services and the potential to improve future employability. These developments suggest that the national states and their domestic economies, such as Australia and the US, are involved in a complex set of strategic repositionings to manage the threat (and opportunities) posed by the rapid growth of the European Higher Education Area and the attempt to build a European Research Area. The entry of the EU into this sphere has clearly tipped the balance of the terrain in a different direction, though the slowing of the European sectoral project, which we address in the following section, will trigger interesting responses. It is not possible to ignore these pressures, given the multiple ways in which the EU has been engaged in inter-regional projects in both the Asian and Latin American regions (Robertson, 2010), and the long shadow cast by the rise of China.

\section{CRISIS, AUSTERITY AND HIGHER EDUCATION GOVERNANCE CHALLENGES FOR EUROPE 2020: A RETURN TO NATIONAL FRONTIERS?}

The global financial crisis in 2008 has generated major challenges for national governments and their higher education institutions on the one hand, and the EU and the legitimacy of its regional project, on the 
other. The scale of the crisis and the challenges ahead are evident in this statement from the European Commission:

The recent economic crisis has no precedent in our generation ... Our industrial production dropped back to the levels of the 1990s and 23 million people - or $10 \%$ of our active population - are now unemployed ... Our public finances have been severely affected, with deficits at 7\% of GDP on average and debt levels at over $80 \%$ of GDP - two years of crisis erasing twenty years of fiscal consolidation. Our exit from the crisis must be the point of entry into a new economy ... What is needed is a strategy to turn the EU into a smart, sustainable and inclusive economy delivering high levels of employment, productivity and social cohesion. This is the Europe 2020 strategy ... Policy instruments were decisively, and massively, used to counteract the crisis. Fiscal policy had, where possible, an expansionary and counter-cyclical role; interest rates were lowered to historical minima while liquidity was provided to the financial sector in an unprecedented way. Governments gave massive support to banks, either through guarantees, recapitalization or through 'cleaning' of balance sheets from impaired assets; other sectors of the economy were supported under the temporary, and exceptional, framework for State aid. (European Commission, 2010: 24)

It is no exaggeration to say that instances of local, regional or global power follow precepts of a global governance agenda compatible with phenomena of regional integration and economic globalization in order to preserve and promote the principles of the capitalist system.

In this section we review some of the early evidence of what this means for Europe's EHEA and ERA projects, and note growing anxieties about the uneven development unfolding across Europe (EC, 2014). One lens through which to view how the European Union sees the challenges facing its ongoing political project following the crisis and austerity measures is via its Europe's 2020 strategy, setting out its strategic priorities for the period 2010-2020. As the EC notes:

Much like most other regions across the world, Europe is going through a period of transformation. The global economic crisis has wiped out years of economic and social progress and exposed structural weaknesses in its economy. Meanwhile, various long-term challenges such as globalization, pressure on natural resources and an ageing population are intensifying. If we are to adapt to this changing reality, Europe can no longer rely on business as usual. (EC, 2014: 3)

Once again, the European Union's state institutions are faced with major challenges: how best to move forward to boost sluggish economic growth, and to stem the rising social and economic inequalities that have cut even deeper into the social fabrics of the various countries making up the European Union. Smart, sustainable and inclusive 
growth is the new strapline (EC, 2014). Five key objectives now guide the Europe 2020 strategy, with renewed emphasis upon the 'social market': increasing employment for 20-64-year-olds; boosting innovation by targeting 3 per cent gross domestic product (GDP) for research and development; reducing school-drop-outs and ensuring social inclusion through education; a reduction in numbers living on or below the poverty line; and limiting greenhouse gas emissions, through climate and energy policy (EC, 2014).

The eurozone crisis - especially with the ongoing challenges posed by the Greek, Portuguese and Spanish economies - has raised new questions about increasingly deeper integration, and what this means for national sovereignty. The European Commission has sought to head off any suggestion that the direction of travel be reversed, and that national governments might selectively withdraw from their commitment to the development of the European project. They argue that:

The crisis has shown us how interlinked our economies are. A housing bubble in one country can impact on neighbouring countries and indeed on all of the Union. This increased economic independence demands a coordinated response, including social partners and civil society. If we act together we can come out of the crisis stronger. In a globalized world, no country can effectively address the challenges it faces by acting alone. This is particularly true for Europe, where tackling such changes is most effective at the European level. (EC, 2014: 5)

The Commission's proposal is to further strengthen the regional coordination of national economic policies through a 'European semester': a specific time of the year when all member states work on the implementation of the Europe 2020 strategy through a national reform and a national convergence programme, on country-specific recommendations from the Commission, and the submission of a draft budget to comply with the Fiscal Compact. A scoreboard will be used to keep track of each member state and alert the EU institutions regarding potential problems. Taken together, these new governance initiatives suggest a much harder edge to the policing of policy implementation than in the past, such as through the use of sanctions. However, as writers such as Beckert (2013) have argued, this more pedagogical element, that is, socializing the member states into closer and ongoing self-assessment and reporting, does not in itself enable the better management of the future, in that the future by definition cannot be known.

It is also clear from data reported in the 2015 Trends Report commissioned by the European University Association (Sursock, 2015), from trends in the 2015 Bologna Process Implementation Report (European 
Commission, 2015), and from the Eurostat 2015 Report on Indicators (Eurostat, 2015) supporting the Europe 2020 strategy, that from 2010 onwards there is considerable shortfall in meeting the EU's EHEA, ERA and Europe 2020 targets. In relation to the EHEA specifically, the Trends and Implementation Reports both note that in 2015 many countries were significantly further away from where they were in 2010 . They point out that the move to new governance structures by many universities across Europe (often referred to as new forms of autonomy, but in truth this meant bringing in new public management as a mode of governing) meant new steering mechanisms were put into place, tied to new fiscal obligations. The financial crisis facing many national governments across Europe has, paradoxically, resulted in tighter bureaucratic control by national governments over their higher education sectors, in turn placing new limits on EU-level power and control. As Sursock (2015: 12) notes in the Trends 2015 Report: 'Although the scope of autonomy is respected, less funding and additional reporting requirements often increase the importance of institutional bureaucracies, limit the capacity of institutions to chart their own course, and erode collegial decision-making'.

With institutions pressed to do more with less following the 2008 financial crisis, institutions have sought to diversify their funding sources, whilst commercial firms, such as recruiters for for-profit providers, and quality assurers, have entered the sector. That Bologna has no funding and financial instruments, and that Europe 2020 and the ERA only address meeting R\&D percentages, has thrown up the limits to the governing of the HE sector at the level of Europe. The crisis has also made visible new struggles over the cultural political economy of this regional sectoral project. Is a new national frontier again being advanced by the national state in this world market-making project? What activities continue to be located at the regional scale, and what ideational work is being done to secure it there? Are alternative spatial projects being mobilized by the state and capital - such as the current round of trade negotiations (for example, the Transatlantic Trade and Investment Partnership, Comprehensive Economic Trade Agreement, Trade in Service Agreement) - that might offer an alternative route forward for bringing higher education into a world market (Robertson and Komljenovic, 2015)?

\section{CONCEPTUALIZING AND THEORIZING THE STATE-REGIONS-FRONTIER RELATION}

In this final section, we return to the challenges and issues confronting researchers interested in studying the production of regions. We began by 
arguing for a more robust conversation between those who study higher education regionalism and the importance of this work to theoretical contributions on understanding regional governance.

In the chapter we have shown the value of developing a cultural political economy approach to region-making to explore the creation of a European Higher Education Area and a European Research Area. Specifically, we have argued that these can be understood as projects whose dynamics are shaped by ongoing transformations in the state and economy, and whose underlying logics at the current time can be better understood in terms of the making of world markets. Yet there is considerable political turbulence in this process as a result of ongoing crisis tendencies confronting the project, as well as ideational struggle over the shape and form of the project.

We also argued that higher education has been progressively drawn into these logics, and that the 'region' - in this case a higher education regional sectoral space - is not only dependent on, but has ongoing effects upon, the socio-political and spatial relations between domestic economies, the (supra-national) region, and the extra-regional, or global. These multiple frontiers - regional, national and global - as the state tries to advance these projects, suggests that theoretical contributions such as regulatory regionalism need to be further nuanced to think about the shifting strategies and frontiers of the state, including its consequent spatial and topological form over time. This means studying these dynamics over time and not only in a narrow temporal window.

We also explored the value of thinking about regions, not in terms of a regionalist ideology, but focusing on underlying logics, processes, mechanisms and outcomes which have socio-spatial manifestations - and in this case, as a result of a particular organization of state rule. They are simultaneously cultural (meaning-making, subjectivities), political (power relations, state) and economic (logic of world market-making, capitalism). They are also a form of sectoral regionalism: the outcome of territorially-based formal and/or informal arrangements arising from strategically selective socio-spatial projects and processes advanced by nationally located states, regional state actors that advance the region 'in and for itself', and the 'extra-regional' or global actors and their institutions. These different spatial frontiers are dynamic, shifting and changing, as a result of struggles over territory, institutions, networks and other forms of organization, and the meanings that they claim for themselves. 


\section{REFERENCES}

Adelman, C. (2008), The Bologna Club: What US Higher Education Can Learn from a Decade of European Reconstruction, Washington, DC: Institute for Higher Education Policy.

van Apeldoorn, B. (2001), The Struggle Over European Order: Transnational Class Agency in the Making of 'Embedded Neo-liberalism'. In A. Bieler and A.D. Morton (eds), Social Forces in the Making of the New Europe, Basingstoke: Palgrave, pp. $70-89$.

Azevedo, M.D. (2014), The Bologna Process and Higher Education in Mercosur: Regionalization or Europeanization? International Journal of Lifelong Education, 33(2), DOI: 10.1080/02601370.2014.891884.

Barroso, J-M. (2005), Strong Universities for Europe. Speech given to the European Universities Association Convention, Glasgow, 2 April, accessed 8 January 2016 at http://www.eua.be/eua/jsp/en/upload/Barroso_speech.1112693429657.pdf.

Beckert, J. (2013), Capitalism as a System of Expectations: Toward a Sociological Microfoundation of Political Economy. Politics and Society, 41(3), $323-350$.

BFUG (2005), From Berlin to Bergen. General Report of the Bologna Follow-up Group to the Conference of European Ministers Responsible for Higher Education. Bergen, 19-20 May. Oslo, 3 May.

BFUG (2016), The Formal Structure of the Bologna Follow-Up Group. Accessed 8 January 2016 at http://www.ehea.info/

Bieler, A. and Morton, A. (eds) (2001), Social Forces in the Making of the New Europe, Basingstoke: Palgrave.

Bishop, J. (2006), The Bologna Process and Australia: Next Steps, Canberra: Australian Federal Department of Education, Skills and Training.

Bologna Declaration (1999), The European Higher Education Area. Joint Declaration of the European Ministers of Education Convened in Bologna at the 19th June, 1999.

Cammack, P. (2015), World Market Regionalism at the Asian Development Bank. Journal of Contemporary Asia, DOI: 10.1080/00472336.2015.1086407.

Collignon, S. (2006), The Lisbon Strategy, Macroeconomic Stability and the Dilemma of Governance with Governments, Boston, MA, USA and London, UK: Harvard University and London School of Economics.

Corbett, A. (2005), Universities and the Europe of Knowledge-Ideas, Institutions and Policy Entrepreneurship in European Union Higher Education Policy, 1955-2005, Basingstoke, UK and New York, USA: Palgrave Macmillan.

Cox, R. (1996), Approaches to World Order, Cambridge: Cambridge University Press.

Dale, R. and Robertson, S. (2002), Regional Organisations as Subjects of Globalisation. Comparative Education Review, 46(1), 10-36.

Elden, S. (2006), Contingent Sovereignty, Territorial Integrity and the Sanctity of Borders. SAIS Review, 26(1), 11-24.

Ercan, F. and Oguz, S. (2006), Rescaling as a Class Relationship and Process: The Case of Public Procurement Law in Turkey. Political Geography, 25, 641-656.

European Commission (2003), Communication from the Commission of 5 February 2003 - The Role of the Universities in the Europe of Knowledge, 
$\operatorname{COM}(2003) 58$ final, accessed 23 April 2016 at http://eur-lex.europa.eu/ legal-content/EN/TXT/HTML/?uri=URISERV:c11067\&from=EN.

European Commission (EC) (2005a), Communication to the Spring European Council. Working Together for Growth and Jobs. A New Start for the Lisbon Strategy, accessed 8 January 2016 at http://europa.eu.int/growthandjobs/.

European Commission (EC) (2005b), Mobilising the Brainpower of Europe: Enabling Universities to Make their Full Contribution to the Lisbon Strategy - European Higher Education in a Worldwide Perspective, Commission Staff Working PaperAnnex to the Communication from the Commission [SEC(2005)518], European Commission: Brussels.

European Commission (EC) (2006), Delivering on the Modernisation Agenda for Universities: Education, Research and Innovation (COM (2006) 208 final), 10 May, European Commission: Brussels.

European Commission (EC) (2012), Communication from the Commission to the European Parliament, the Council, the European Economic Social Committee and the Social Committee of the Regions: A Reinforced European Research Area Partnership for Excellence and Growth, COM (2012) 392 final, Brussels: European Commission.

European Commission (2014), EU Annual Growth Survey 2015: A new Momentum for Jobs, Growth and Investment, Brussels: European Commission, accessed 23 April 2016 at http://europa.eu/rapid/press-release_IP-14-2235_en.htm.

European Commission (EC) (2015), Bologna Process Implementation Report, 2015, Brussels: European Commission.

European Council (2000), Conclusions of the European Lisbon Council, 23-24 March, SN100/00, available at http://www.europarl.europa.eu/summits/ lis1_en.htm.

European Council (2005), Presidency Conclusions 22 and 23 March, Brussels [DOC/05/1].

Eurostat (2015), Smarter, Greener, More Inclusive? Indicators to Support the Europe 2020 Strategy - 2015 edition, accessed 23 April 2016 at http:// ec.europa.eu/eurostat/web/europe-2020-indicators/europe-2020-strategy/ publications.

Figel, J. and Bishop, J. (2007), Joint Declaration between the European Union and Australia. European Commission and the Government of Australia wish to reinforce co-operation in the fields of education and training, Brussels: European Commission.

Gornitzka, A. (2005), Coordinating Policies for a 'Europe of knowledge': Emerging Practices of the 'Open Method of Coordination' in Education and Research. Working Paper 16, accessed 14 January 2016 at http: www.arena.uio.no.

Hameiri, S. (2013), Theorising Regions through Changes in Statehood: Rethinking the Theory and Method of Comparative Regionalism. Review of International Studies, 39, 313-335.

Hameiri, S. and Jayasuriya, K. (2011), Regulatory Regionalism and the Dynamics of Territorial Politics: The Case of the Asia Pacific. Political Studies, 59(1), 20-37.

Harmsen, R. (2013), The Bologna Process and New Modes of Governance: Logics and Limits of Arena Shaping. Presented at EUSA 13th Biennial Conference, Baltimore, MA, 9 May.

Hartmann, E. (2008), Bologna Goes Global: A New Imperialism in the Making. Globalisation, Societies and Education, 6(3), 207-220. 
Hettne, B. (2005), Beyond the 'New Regionalism'. New Political Economy, 10(4), $543-571$.

Hingel, A.J. (2001), Education Policies and European Governance: Contribution to the Inter-service Groups on European Governance. Brussels: European Commission, Directorate-General for Education and Culture (Unit A1: Development of Educational Policies), also published in the European Journal for Education Law and Policy, 5, 7-16.

Huisman, J. and van der Wende, M. (2004), The EU and Bologna: Are Supra- and International Initiatives Threatening Domestic Agendas? European Journal of Education, 39(3), 349-357.

Jaschik, S. (2006), Making Sense of 'Bologna Degrees'. Inside Higher Education. 6 November, available at http://insidehighered.com/news/2006/11/06/bologna.

Jayasuriya, K. (2003), Introduction: Governing the Asia-Pacific-beyond the 'New Regionalism'. Third World Quarterly, 24(2), 199-215.

Keeling, R. (2006), The Bologna Process and the Lisbon Research Agenda: The European Commission's Expanding Role in Higher Education Discourse. European Journal of Education, 41(2), 203-223.

Kok, W. (2004), Facing the Challenge Ahead: The Lisbon Strategy for Growth and Employment, Report from the High Level Group, Brussels: European Commission.

Ravinet, P. (2008), From Voluntary Participation to Monitored Coordination: Why European Countries feel Increasingly Bound By their Commitment to the Bologna Process. European Journal of Education, 43(3), 353-367.

Robertson, S. (2008a), Embracing the Global: Crisis and the Creation of a New Semiotic Order to Secure Europe's Knowledge-Based Economy. In N. Fairclough, R. Wodak and B. Jessop (eds), Education and the Knowledgebased Economy in Europe, Rotterdam: Sense Publications, pp. 89-108.

Robertson, S. (2008b), 'Europe/Asia' Regionalism, Higher Education and the Production of World Order. Policy Futures in Education, 6(6), 718-729.

Robertson, S.L. (2010), The EU, Regulatory State Regionalism, and Higher Education. Globalisation, Societies and Education, 8(1), 23-37.

Robertson, S. (2014), Higher Education Regionalising Projects in a Globalising World: A 'Variegated Regionalism' Account. Paper presented to ECPR, Glasgow, 3-6 September.

Robertson, S. and Dale, R. (2015), Critical Cultural Political Economy of the Globalisation of Education. Globalisation, Societies and Education, 13(1), 149-170.

Robertson, S. and Keeling, R. (2008), Stirring the Lions: Strategy and Tactics in Global Higher Education. Globalisation, Societies and Education, 6(3), 221-240.

Robertson, S. and Komljenovic, J. (2015), Forum Shifting and Shape Making in Europe's Negotiations on (Education) Trade in Services Education. Presented to the Education and Trade Panel ECPR, Montreal, 26-28 August.

Rodrigues, M-J. (ed.) (2002), The New Knowledge Economy in Europe. Cheltenham, UK and Northampton, MA, USA: Edward Elgar.

Sursock, A. (2015), Trends 2015: Learning and Teaching in European Universities, Brussels: European Universities Association.

Teichler, U. and Kehm, B. (1995), Towards a New Understanding of the Relationships between Higher Education and Employment. European Journal of Education, 30(2), 115-132. 
Walters, W. and Haar, J. (2005), Governing Europe: Discourse, Governmentality and European Integration. London, UK and New York, USA: Routledge.

World Trade Organization (WTO) (2007), International Trade Statistics, 2006, WTO: Geneva.

Zeitlen, J. and Pochet, P. (eds) with Magnusson, L. (2005), The Open Method of Coordination in Action, Brussels: Peter Lang.

Zgaga, P. (2006), Looking Out: The Bologna Process in a Global Setting - on the External Dimension of the Bologna Process, Oslo: Norwegian Ministry of Education Research. 